\title{
Correction to: Dabigatran-Induced Massive Spontaneous Hemothorax
}

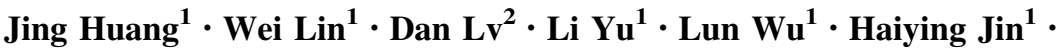 \\ Zaichun Deng ${ }^{2} \cdot$ Qunli Ding ${ }^{2}$
}

\section{Correction to: Drug Saf - Case Rep (2017)4:12 DOI 10.1007/s40800-017-0054-z}

Page 3, Table 2, 'Renal function indexes at different dates after admission': The cell entry in column 2, detailing the patient's urea concentration $(\mu \mathrm{mol} / \mathrm{L})$ on Day 1 ,

Which previously read

"5970",

should read

“597.00".
Open Access This article is distributed under the terms of the Creative Commons Attribution-NonCommercial 4.0 International License (http://creativecommons.org/licenses/by-nc/4.0/), which permits any noncommercial use, distribution, and reproduction in any medium, provided you give appropriate credit to the original author(s) and the source, provide a link to the Creative Commons license, and indicate if changes were made.

The online version of the original article can be found under doi:10.1007/s40800-017-0054-z.

Qunli Ding

ccding2005@163.com

1 Department of Pharmacy, The Affiliated Hospital of Medical College, Ningbo University, No.247, Renmin Road, Jiangbei District, Ningbo 315020, Zhejiang, China

2 Department of Respiratory Medicine, The Affiliated Hospital of Medical College, Ningbo University, No.247, Renmin Road, Jiangbei District, Ningbo 315020, Zhejiang, China 